\title{
Chemical characteristics and digestibility of forage maize hybrids associated with foliar fungicide application
}

\section{Características bromatológicas e digestibilidade de híbridos de milho forrageiro associados à aplicação de fungicida foliar}

\author{
Marcelo Cruz Mendes ${ }^{1 *}$; Alan Junior Stadler²; Kathia Szeuczuk de Oliveira²; \\ Mikael Neumann'; Samuel Schneider de Jesus ${ }^{3}$; Marcos Ventura Faria ${ }^{1}$
}

\section{Highlights:}

Application of fungicide in forage maize hybrids decreased NDF and ADF.

Sowing in December negatively influenced forage maize hybrids.

Hybrids with highly vitreous endosperm obtained the highest contents of NDF and ADF.

\begin{abstract}
The objective of this study was to evaluate the effect of foliar fungicide application on the chemical characteristics and in situ digestibility of forage and silage in forage maize hybrids with different grain textures in two sowing seasons. A randomized complete block design was used with four replications, in a 4 × 2 factorial arrangement, 4 hybrids, with and without foliar fungicide application, in two sowing seasons. The hybrids used were DKB240PRO, AS1572PRO, 32R48YH and AG8690PRO3. Data were tested by analysis of variance; the means were compared by Tukey's test at $5 \%$ probability and two nonorthogonal contrasts were performed. The application of fungicide on forage maize hybrids reduced the content of neutral detergent fiber (NDF), acid detergent fiber (ADF), soft dough stage and in the silage produced. The sowing season in December negatively influenced the chemical parameters of forage maize hybrids, compared to sowing in October. Hybrids with highly vitreous endosperm presented the highest contents of NDF and ADF, soft dough stage and in the silage produced. The application of fungicide (trifloxystrobin + prothioconazole) at the V8 and R1 stages positively influenced in situ digestibility soft dough stage and in the silage produced, depending of the sowing season.
\end{abstract}

Key words: Acid detergent fiber. Forage. Neutral detergent fiber. Silage. Zea mays L.

\section{Resumo}

O objetivo foi avaliar o efeito da aplicação foliar de fungicida sobre as características bromatológicas e digestibilidade in situ de forragem e silagem em híbridos de milho forrageiro com diferentes texturas de grãos em duas épocas de semeadura. O delineamento foi blocos casualizados, em esquema fatorial 4x2, 4 híbridos, sem e com aplicação de fungicida, em duas épocas de semeadura. Os híbridos utilizados foram DKB240PRO, AS1572PRO, 32R48YH e AG8690PRO3. Os dados obtidos foram submetidos

${ }^{1}$ Profs. Drs., Programa de Pós-Graduação em Agronomia na Área de Produção Vegetal, Universidade Estadual do Centro-Oeste, UNICENTRO, Centro de Ciências Agrárias e Ambientais, Guarapuava, PR, Brasil. E-mail: mcmendes@unicentro.br; neumann. mikael@hotmail.com; mfaria@unicentro.br

2 Mestres em Produção Vegetal, UNICENTRO, Guarapuava, PR, Brasil. E-mail: alan_stadler@hotmail.com; kahh.szeuczuk@, gmail.com

3 Discente do Curso de Graduação em Agronomia, UNICENTRO, Guarapuava, PR, Brasil. E-mail: schneeider12@gmail.com

* Author for correspondence

Received: Mar. 19, 2020 - Approved: June 09, 2020 
à análise de variância, as médias comparadas pelo teste de Tukey e realizados dois contrastes não ortogonais. A aplicação de fungicida em híbridos de milho forrageiros reduziu os teores de fibra em detergente neutro (FDN) e fibra em detergente ácido (FDA) obtidos no ponto de forragem e na silagem produzida. A época de semeadura em dezembro influenciou negativamente os parâmetros bromatológicos de híbridos de milho forrageiros, em comparação com a semeadura em outubro. Os híbridos de endosperma de alta vitreosidade obtiveram os maiores teores de FDN e FDA, no ponto de forragem e na silagem produzida. A aplicação de fungicida (trifloxostrobina + protioconazol) em V8 e R1 influenciou positivamente a digestibilidade in situ no ponto de forragem e na silagem produzida, independente da época de semeadura.

Palavras-chave: Fibra em detergente ácido. Forragem. Fibra em detergente neutro. Silagem. Zea mays L.

\section{Introduction}

The State of Paraná has a high potential for technological development in the sectors of beef and dairy cattle farming. Several production systems have been distributed in the most distinct regions of the State. However, satisfactory performance has not always been achieved, and there is a need for a kind of food of quality that makes the system viable and guarantees gains in animal production (Neumann, Figueira, Faria, Mendes, \& Carneiro, 2015).

Maize silage is a food of major importance in the farming section due to its nutritional quality, and mainly its low content of fibers, representing about 50\% sum of animal diet (Haerr, Lopes, Pereira, Fellwos, \& Cardoso, 2015). Nonetheless, the quality of forage may vary because of the hybrid and the management system employed. This quality will directly influence the gain in animal production, justifying the need to know the chemical composition of the forage employed (Carvalho et al., 2015).

Currently, chemical analyses have been presented as an excellent strategy to assess and quantify the chemical composition of the food, helping to define techniques that improve hybrid cultivations for the production of forage. This fact highlights the importance of the determination of forage quality through chemical characteristics, such as acid detergent fiber (ADF) and neutral detergent fiber (NDF), which correspond to the least digestible fractions of the forage (Kalebich et al., 2017).
Another significant factor to determine the quality of forage and silage produced is the in situ dry matter digestibility. Nowadays, this characteristic has been commonly assessed, as it allows a safer indication on the nutritional value of the hybrids. The main advantage of this method is to simultaneously process a great number of samples, and, in this way, determine the energy value of the forage and silage for animal feed (Mendes, Von Pinho, Pereira, Faria, \& Souza, 2008; Rossi, Faria, Mendes, Neumann, Gabriel \& Del Conte, 2016a).

In order to obtain forage with a high energy value, there is an attempt to find acceptable contents of fiber, over $50 \%$ dry matter digestibility and thus increase the dry matter intake of the animal (Marafon et al., 2015). This improvement may be achieved through the choice of the sowing season that directly influences the final quality of the silage and grain (Mendes, Pereira, \& Souza, 2015b).

The application of fungicide in maize hybrids for grain production has been presented as an efficient technique to increase the gain in grain yield. However, only few Studies report the influence of application of fungicide on the chemical characteristics. According to Venancio, Rodrigues, Begliomini and Souza (2009), fungicide application tends to cause changes in plant physiology that may improve the nutritional value of the forage. As for Haerr et al. (2016), the application of foliar fungicide linearly reduces the contents of fiber present in the forage. 
In this sense, the present study aimed at assessing the effect of foliar fungicide application on the chemical characteristics and in situ digestibility of forage and silage in forage maize hybrids with different grain textures in two sowing seasons.

\section{Material and Methods}

Two experiments were installed in two distinct sowing seasons in the growing season of 2015/16, in the experimental field of the State University of the Center-West, CEDETEG campus, in the municipality of Guarapuava, State of Paraná, at an average altitude of 1,028 meters, in a no-till system.

The predominant climate in the region is humid subtropical mesothermal (Hsm) without a defined dry season, with mild summers, and winters with severe and frequent frosts, according to Köppen (Peel, Finlayson, \& McMahon, 2007); the average annual temperature is $16.8{ }^{\circ} \mathrm{C}$, maximum average $36{ }^{\circ} \mathrm{C}$, and minimum average $6.8^{\circ} \mathrm{C}$. The average annual rainfall is $1,500 \mathrm{~mm}$, and relative humidity is $77.9 \%$. The soil is classified as Typical Dystrophic Bruno Latosol, with a very clayey texture.

This was a $4 \times 2$ factorial randomized block design with four replications, with 4 hybrids of maize, without and with the application of fungicide, evaluated in 2 sowing seasons. The maize hybrids used were classified by the analysis of vitreous endosperm in two groups: DKB240PRO and AS1572PRO with medium vitreous endosperm (MEDIUM VIT up to $65 \%$ vitreous endosperm), P32R48YH and AG8690PRO3 with high vitreous endosperm (HIGH VIT higher than $65 \%$ vitreous endosperm).

The sowing seasons were defined based on the agricultural zoning for the region of Guarapuava; the first sowing season was in October, classified as early sowing and the preferred season for the crop, since it coincides with the stage at which the plant has the highest index of leaf area and the longest days of the year. The second season was in December, characterized as late sowing, when the temperature tends to decrease and the days are shorter, different from the observed when sowing in October.

The chemical control with foliar fungicides consisted of two levels. The first without foliar application of fungicide (control), and the second with two foliar applications of fungicide (Trifloxystrobin $150.0 \mathrm{~g} \mathrm{~L}^{-1}\left(15.0 \% \mathrm{~m} \mathrm{v}^{-1}\right)+$ Prothioconazole 175.0 $\mathrm{g} \mathrm{L}^{-1}\left(17.5 \% \mathrm{~m} \mathrm{v}^{-1}\right)$ in the dose of $0.4 \mathrm{~L} \mathrm{ha}^{-1}$ at the V8 stage ( 8 expanded leaves) and at the $\mathrm{R} 1$ stage (reproductive).

The plots comprised four rows of five meters, with row spacing of $0.45 \mathrm{~m}$, and density after thinning of 75,500 plants ha-1. Sowing was carried manually, using fertilization of $\mathrm{Kg} \mathrm{ha}^{-1}$ basis of NPK 08-28-16 formulation; when the plants achieved between four and five expanded leaves (V4-V5), $250 \mathrm{Kg} \mathrm{ha}^{-1}$ granular urea was applied as topdressing $(46 \% \mathrm{~N})$, totaling $120 \mathrm{~kg} \mathrm{~N} \mathrm{ha}^{-1}$.

Fungicide was applied with a backpack $\mathrm{CO}_{2}$ pressurized sprayer, equipped with four simple nozzles, spaced $50 \mathrm{~cm}$ apart, representing an application volume of $160 \mathrm{~L} \mathrm{ha}^{-1}$ and traverse speed of $3.6 \mathrm{~km} \mathrm{~h}^{-1}$.

In order to quantify the chemical parameters and digestibility of forage and silage, 8 plants were collected from a central row of each plot, between the reproductive stages of floury grains and hard starches, $3 / 4$ denominated point of the milkline (forage point), with dry matter percentage between 30 and $37 \%$. Plants were harvested manually, at a cutting height of $20 \mathrm{~cm}$ from the ground; the material collected was chopped with a stationary chopper (Nogueira ${ }^{\circledR}$, EM 640), adjusted to obtain medium particles of $2 \mathrm{~cm}$.

After, chopped plants were homogenized for taking a sample of each plot, approximately $200 \mathrm{~g}$, which was dried in a forced ventilation kiln oven at $55^{\circ} \mathrm{C}$, until constant weight. Afterwards, samples were weighed again for the determination of the forage dry matter. 
Soon after, the resulting material was ensiled in PVC silos for determination of chemical characteristics of the silage; they were opened 180 days after sealing, and a homogeneous sample of $200 \mathrm{~g}$ was collected and dried in a forced ventilation kiln oven until constant weight. After that, they were weighed again to determine the silage dry matter. After drying, samples were ground in a Wiley mill, with $1 \mathrm{~mm}$ sieves, for chemical and digestibility analyses, which were performed at the Center Lab of Animal Production of the State University of the Center-West.

The following chemical characteristics were evaluated: percentage of neutral detergent fiber of forage (NDFF); neutral detergent fiber of silage (NDFS), using $0.5 \mathrm{~mL}$ thermostable alphaamylase for the determination of NDF of each sample; percentage of acid detergent fiber of forage (ADFF); acid detergent fiber of silage (ADFS), both determined through a non-sequential analysis, according to the methodology described by Van Soest, Robertson and Lewis (1991); in situ forage digestibility (DIGF) and in situ silage digestibility (DIGS).

Vitreous endosperm was analyzed for characterization of the forage hybrids used in this experiment in order to contrast it with the information obtained by the breeder companies of the seeds, employing the methodology proposed by Dombrink and Bietz (1993).

For the analysis of vitreous endosperm, dry maize grains were collected at physiological maturity. In order to reduce the effect of the position of the grain in the spike, 100 grains were selected at random from each experimental plot, and were divided into 10 groups homogeneous in size and shape, so that each group had 10 grains (Rossi et al., 2016a).

After the analysis of vitreous endosperm, hybrids were divided into two groups with regard to the percentage of vitreous endosperm; the first group had medium vitreous endosperm $(<65 \%$ vitreous endosperm), the DKB240PRO and AS1572PRO hybrids, and the second group had high vitreous endosperm ( $>65 \%$ vitreous endosperm), P32R48YH and AG8690PRO3 hybrids.

The determination of in situ digestibility of forage and silage of the forage maize hybrids was performed in accordance with the methodology proposed by Pereira, Von Pinho, Souza, Pereira, Santos \& Borges (2012). A sample of each plot was in a forced ventilation kiln oven at $55{ }^{\circ} \mathrm{C}$, for 72 $\mathrm{h}$, and subsequently incubated in the rumen. For ruminal incubation, small nylon bags, $10 \times 15 \mathrm{~cm}$, containing five grams of forage or silage dried at 55 ${ }^{\circ} \mathrm{C}$ and ground in a Wiley mill with $1 \mathrm{~mm}$ sieves.

In the assessment of in situ digestibility of forage and silage, a fistulated Jersey animal was used. Two incubations were carried out; the first one consisted of 64 bags with forage, and the second incubation with 64 bags with silage, relating to the 4 hybrids assessed, without and with foliar fungicide application, with four replications and in two sowing seasons. The animal had been previously adapted to a standard diet of $20 \%$ concentrate and $80 \%$ maize silage for two weeks, according to the methodology proposed by Rossi

et al. (2016a).

After $24 \mathrm{~h}$ incubation, all the bags were removed and immersed in icy water to cease microbial activity. Then, they were washed in running water until the water was clear. The bags were taken to a forced ventilation oven at $105{ }^{\circ} \mathrm{C}$ for $48 \mathrm{~h}$, and then weighed. After that, the in situ digestibility of forage and silage was determined after $24 \mathrm{~h}$ time of incubation, and the results were expressed in percentage regarding the initial dry matter. This study was approved by the ethics committee in animal experimentation, with number $031 / 2017$.

Data obtained for each variable were tested by analyses of variance and covariance; the means were compared to each other by Tukey's test at 5\% probability, using the statistical software Sisvar $^{\circledR}$ (Ferreira, 2014). 
Two non-orthogonal contrasts were used aiming at comparing: with and without foliar fungicide application and sowing seasons (October and December), in relation to the characteristics neutral detergent fiber of forage (NDFF) and silage (NADFS), acid detergent fiber of forage (ADFF) and silage (ADFS) obtained for the different hybrids, two treatments (with and without fungicide), in two sowing seasons in the municipality of Guarapuava, State of Paraná, in the growing season 2015/2016.

\section{Results and Discussion}

Considering the analysis of variance, significant effects were detected $(\mathrm{p}<0.01)$ for season group and $(p<0.05)$ for the double interaction hybrid $\mathrm{x}$ fungicide for neutral detergent fiber of forage (NDFF), for the triple interaction hybrid $\mathrm{x}$ fungicide $\mathrm{x}$ season for acid detergent fiber of forage (ADFF) and significant effect $(p<0.01)$ for hybrid, fungicide and double interaction hybrid $\mathrm{x}$ season for digestibility of forage (DIGF).

For neutral detergent fiber of silage (NDFS) and acid detergent fiber of silage (ADFS), there was a significant effect $(p<0.01)$ for the group and the triple interaction hybrid $\mathrm{x}$ fungicide $\mathrm{x}$ season, and for digestibility of silage, a significant effect $(p<0.01)$ was observed for fungicide, group and double interaction hybrid $\mathrm{x}$ season.

For NDFF, there was a difference between the hybrids in both sowing seasons (Table 1). In this way, it can be observed that in season 1, the DKB240PRO, AS1572PRO and 32R48YH hybrids lesser obtained the NDFF percentages without the application of fungicide, and hybrid AG8690PRO3 (56.08\%) obtained the highest percentage of NDFF without foliar fungicide application. With regard to the application of fungicide in season 1 , it can be observed that there was a statistical difference between the hybrids, where DKB240PRO (44.72\%) and AS1572PRO (40.14\%) hybrids obtained the lowest percentages of NDFF with the application of fungicide.

For season 2, without the application of fungicide, 32R48YH and AG8690PRO3 hybrids presented the highest contents of NDFF, differing from the other hybrids, and with the application of fungicide, DKB240PRO hybrid stands out as the one with the lowest content of NDFF, being different from the others in an isolated way.

With the application of fungicide in season 1, it can be observed that DKB240PRO, AS1572PRO and AG8690PRO3 hybrids obtained a reduction in the contents of NDFF in the order of $4.02 \%$, $8.64 \%$ and $9.26 \%$, respectively. In season 2 , this decrease in the contents of NDFF was found only for AG8690PRO3, with a decrease of 7.13\% NDFF with the application of fungicide.

It is important to point out that there was a difference in the contents of NDFF between the groups of vitreous endosperm (medium and high), demonstrating that the hybrids with medium vitreous endosperm showed lower NDFF contents, if compared to the hybrids of high vitreous endosperm. According to Rossi, Faria, Mendes, Possatto, Neumann \& Jobim (2016b), the hybrids with medium vitreous endosperm (dent and semident) are more accepted for the use in animal feed. 
Table 1

Mean results for neutral detergent fiber of forage (NDFF) and acid detergent fiber of forage (ADFF) obtained for different maize hybrids, with and without foliar fungicide application, in two sowing seasons in the municipality of Guarapuava, State of Paraná, in the growing season of 2015/16

\begin{tabular}{|c|c|c|c|c|c|c|}
\hline \multirow{4}{*}{ Hybrids } & \multicolumn{6}{|c|}{ NDFF (\%) } \\
\hline & \multicolumn{3}{|c|}{ Season 1} & \multicolumn{3}{|c|}{ Season 2} \\
\hline & \multicolumn{2}{|c|}{ Fungicide } & \multicolumn{4}{|c|}{ Fungicide } \\
\hline & Without & With & Reduction & Without & With & Reduction \\
\hline DKB240PRO & $48.74 \mathrm{bA}$ & $44.72 \mathrm{abB}$ & 8.24 & $52.81 \mathrm{bA}$ & $49.34 \mathrm{aA}$ & 6.57 \\
\hline AS1572PRO & $48.78 \mathrm{bA}$ & $40.14 \mathrm{bB}$ & 17.71 & $51.52 \mathrm{bA}$ & $50.51 \mathrm{bA}$ & 1.96 \\
\hline Medium VIT & $48.76 \mathrm{bA}$ & $42.43 \mathrm{bB}$ & & $52.16 \mathrm{bA}$ & $49.93 \mathrm{bA}$ & \\
\hline 32R48YH & $50.41 \mathrm{bA}$ & $48.32 \mathrm{aA}$ & 4.14 & $58.49 \mathrm{aA}$ & $55.79 \mathrm{aA}$ & 4.61 \\
\hline AG8690PRO3 & $56.08 \mathrm{aA}$ & $46.82 \mathrm{aB}$ & 16.51 & $60.35 \mathrm{aA}$ & $53.22 \mathrm{abB}$ & 11.81 \\
\hline \multirow[t]{2}{*}{ High VIT } & $53.24 \mathrm{aA}$ & $47.57 \mathrm{aB}$ & & $59.42 \mathrm{aA}$ & $54.51 \mathrm{aB}$ & CV(\%) 5.25 \\
\hline & \multicolumn{6}{|c|}{ ADFF (\%) } \\
\hline \multirow{3}{*}{ Hybrids } & \multicolumn{3}{|c|}{ Season 1} & \multicolumn{3}{|c|}{ Season 2} \\
\hline & \multicolumn{3}{|c|}{ Fungicide } & \multicolumn{3}{|c|}{ Fungicide } \\
\hline & Without & With & Reduction & Without & With & Reduction \\
\hline DKB240PRO & $24.81 \mathrm{aA}$ & $22.09 \mathrm{aA}$ & 10.96 & $25.82 \mathrm{bA}$ & $22.63 \mathrm{bB}$ & 12.35 \\
\hline AS1572PRO & $24.89 \mathrm{aA}$ & $18.14 \mathrm{bB}$ & 27.11 & $25.57 \mathrm{bA}$ & $25.60 \mathrm{abA}$ & 0.00 \\
\hline Medium VIT & $24.85 \mathrm{aA}$ & $20.11 \mathrm{aB}$ & & $25.69 \mathrm{bA}$ & $24.11 \mathrm{bA}$ & \\
\hline 32R48YH & $25.23 \mathrm{aA}$ & $22.41 \mathrm{aB}$ & 11.17 & $30.05 \mathrm{aA}$ & $28.55 \mathrm{aA}$ & 4.99 \\
\hline AG8690PRO3 & $24.71 \mathrm{aA}$ & $20.19 \mathrm{abB}$ & 18.29 & $32.73 \mathrm{aA}$ & $26.07 \mathrm{abB}$ & 20.34 \\
\hline High VIT & $24.96 \mathrm{aA}$ & $21.29 \mathrm{aB}$ & & $31.39 \mathrm{aA}$ & $27.31 \mathrm{aB}$ & CV(\%) 7.73 \\
\hline
\end{tabular}

Means followed by similar lowercase letters, in the same column, for the hybrids, and uppercase letters, in the same row, for the foliar fungicide application do not statistically differ from each other by Tukey's test at $5 \%$ probability.

The main factor that justifies the preference for forage maize hybrids with lower vitreous endosperm for animal feed is the result of the higher digestibility of the hard part of the grain, which is the result of the reduced presence of a protein matrix in this region of the grain, with a hydrophobic profile and makes the enzyme attack more difficult (Momany et al., 2006). In this way, forage from maize hybrids with medium vitreous endosperm tends to be more digestible than the hybrids with high vitreous endosperm (Arcari, Martins, Tomazi, \& Santos, 2016), playing an important role in the quality and final use of the food (Giuberti et al., 2014; Rossi et al., 2016a).

The hybrids with semi-hard and hard endosperm (high vitreous endosperm) are characterized by a harder grain, basically formed by a discontinuous protein matrix that, when present in the endosperm, make a hydrophobic barrier, encapsulating the starch granule in a protein matrix (Momany et al., 2006), making the enzyme attack of the maize more difficult, and decreasing digestibility, being undesirable in the nutritional perspective of animal feed (Rossi et al., 2016a).

The fiber portion represented by the NDF values is formed by cellulose, hemicellulose and lignin, forage digestibility is inversely proportional to these compounds (Mendes et al., 2008; Lima et al., 2012). In this way, most NDFF values found are below those reported by Ribas et al. (2007), who assessed two forage maize hybrids and obtained contents over $51 \% \mathrm{NDF}$, verifying that the highest 
values of this fiber portion tend to limit voluntary consumption, resulting in a lower productive performance by animals.

For ADFF, there was a statistical difference between the hybrids in season 1 only for the application of fungicide, in which AS1572PRO and AG8690PRO3 hybrids obtained the lowest contents of ADFF. For season 2, there was a difference between the hybrids for application of fungicide, where the DKB240PRO and AS1572PRO hybrids obtained the lowest contents of ADFF with application of fungicide.

A similar fact occurred for the contents of ADFF in both sowing seasons, where in season 1, AS1572PRO, 32R48YH and AG8690PRO3 hybrids showed a reduction up to $6 \%$ in ADFF content. For season 2, a decrease in the contents of ADFF was verified only for DKB240PRO and AG8690PRO3 hybrids (3.19\% and 6.6\%, respectively). Such results demonstrate that the application of foliar fungicide in forage maize hybrids can reduce the contents of fibers (non-soluble carbohydrates), improving the chemical and nutritional quality of the forage.

ADF represents the non-digestible fibers for the animal, characterized through digestion in acid detergent, diluting the cell content and hemicellulose (Rossi et al., 2016a), being only lignin and cellulose left. In this way, these parameters influence on important characteristics in the nutrition of ruminants, such as digestibility, energy value, ruminal fermentation and ingestion control (Vieira et al., 2013).

The contents of ADF should be equal to or lower than $30 \%$ to obtain silage of good quality (Mendes et al., 2008; Neumann, Ost, Pellegrini, \& Defaveri, 2008); these values were achieved in the present study in season 1. Thus, Moraes, Jobim, Silva and Marquardt (2013), when comparing and assessing the chemical composition of maize hybrids, obtained ADF values around $28 \%$, confirming the values obtained by Vieira et al. (2013), with 29\%, and the contents obtained herein.
In this sense, Moraes et al. (2013) and Vieira et al. (2013) were successful with the ADF values obtained, with contents below $20 \%$, which, directly affects the apparent digestibility of the forage. In addition. In this way, Marcondes et al. (2016) and Gralak et al. (2014), when assessed the agronomic and forage potential of maize lineages in the region of Guarapuava, State of Paraná, achieved values around $33 \%$ for ADF.

For the NDFS characteristic (Table 2), there was a difference between hybrids without and with the application of fungicide in both sowing seasons. Thus, it is important to point out that without the application of fungicide, in season 1, hybrid AS1572PRO demonstrated the lowest content of NDFS, differing from the other hybrids; with the application of fungicide it was possible to observe that hybrid DKB240PRO presented the lowest content of NDFS, being statistically different from the other hybrids assessed. As for the application of fungicide, it was observed that there was a difference between the treatment without fungicide and the treatment with fungicide application, in both sowing seasons. In this way, it can be highlighted that DKB240PRO, 32R48YH and AG8690PRO3 hybrids presented decreases in the contents of NDFF for season 1. As for season 2, DKB240PRO, AS1572PRO and 32R48YH hybrids presented a decrease in the contents of NDFS with the application of fungicide.

NDF values of forage or silage are basically influenced by sowing density, differences between genotypes, stresses caused by the environmental conditions dependent on the sowing seasons, agricultural harvest and possibly the occurrence of diseases Mendes, Gabriel, Faria, Rossi and Possatto (2015a); Venancio et al. (2009). Regarding the occurrence of diseases, Haerr et al. (2016) state that foliar diseases tend to modify the chemical characteristics of the plant, due to the increase in the lignin production as a defense mechanism to prevent the entrance of pathogens inside the cells, increasing the contents of NDF and ADF of silage. 
Table 2

Mean results for neutral detergent fiber of silage (NDFS) and acid detergent fiber of silage (ADFS) obtained for different maize hybrids, with and without foliar fungicide application, in two sowing seasons in the municipality of Guarapuava, State of Paraná, in the growing season of 2015/16

\begin{tabular}{|c|c|c|c|c|c|c|}
\hline \multirow{4}{*}{ Hybrids } & \multicolumn{6}{|c|}{ NDFS (\%) } \\
\hline & \multicolumn{3}{|c|}{ Season 1} & \multicolumn{3}{|c|}{ Season 2} \\
\hline & \multicolumn{2}{|c|}{ Fungicide } & \multicolumn{4}{|c|}{ Fungicide } \\
\hline & Without & With & Reduction & Without & With & Reduction \\
\hline DKB240PRO & $46.94 \mathrm{aA}$ & $35.33 \mathrm{bB}$ & 24.73 & $71.08 \mathrm{aA}$ & $67.58 \mathrm{aB}$ & 4.92 \\
\hline AS1572PRO & $41.24 \mathrm{bA}$ & $41.02 \mathrm{aA}$ & 0.53 & $65.20 \mathrm{bA}$ & $61.71 \mathrm{bB}$ & 5.35 \\
\hline Medium VIT & $44.09 \mathrm{bA}$ & $38.17 \mathrm{bB}$ & & $68.14 \mathrm{aA}$ & $64.65 \mathrm{aB}$ & \\
\hline 32R48YH & $48.11 \mathrm{aA}$ & $41.88 \mathrm{aB}$ & 12.94 & $67.13 \mathrm{abA}$ & $61.84 \mathrm{bB}$ & 7.88 \\
\hline AG8690PRO3 & $45.90 \mathrm{aA}$ & $40.11 \mathrm{aB}$ & 12.61 & $65.61 \mathrm{bA}$ & $63.62 \mathrm{abA}$ & 3.03 \\
\hline \multirow[t]{2}{*}{ High VIT } & $47.01 \mathrm{aA}$ & $40.99 \mathrm{aB}$ & & $66.37 \mathrm{aA}$ & $62.73 \mathrm{aB}$ & CV(\%) 4.25 \\
\hline & \multicolumn{6}{|c|}{ ADFS (\%) } \\
\hline \multirow{3}{*}{ Hybrids } & \multicolumn{3}{|c|}{ Season 1} & \multicolumn{3}{|c|}{ Season 2} \\
\hline & \multicolumn{2}{|c|}{ Fungicide } & \multicolumn{4}{|c|}{ Fungicide } \\
\hline & Without & With & Reduction & Without & With & Reduction \\
\hline DKB240PRO & $26.63 \mathrm{bA}$ & $21.81 \mathrm{abB}$ & 18.09 & $34.64 \mathrm{aA}$ & $25.23 \mathrm{bcB}$ & 27.16 \\
\hline AS1572PRO & $28.78 \mathrm{abA}$ & $19.98 \mathrm{bB}$ & 30.57 & $27.16 \mathrm{cA}$ & $27.07 \mathrm{abA}$ & 0.33 \\
\hline Medium VIT & $27.71 \mathrm{aA}$ & 20.89 bB & & 30.85 aA & $26.21 \mathrm{aB}$ & \\
\hline 32R48YH & $30.43 \mathrm{aA}$ & $25.03 \mathrm{aB}$ & 17.74 & $33.55 \mathrm{abA}$ & $29.17 \mathrm{aB}$ & 13.05 \\
\hline AG8690PRO3 & $28.07 \mathrm{abA}$ & $22.86 \mathrm{abB}$ & 18.56 & $30.62 \mathrm{bcA}$ & $23.15 \mathrm{cB}$ & 24.39 \\
\hline High VIT & $23.94 \mathrm{aA}$ & $23.94 \mathrm{aA}$ & & $32.08 \mathrm{aA}$ & $26.16 \mathrm{aB}$ & CV(\%) 7.19 \\
\hline
\end{tabular}

Means followed by similar lowercase letters, in the same column, for the hybrids, and uppercase letters, in the same row, for the foliar fungicide application do not statistically differ from each other by Tukey's test at 5\% probability.

For the contents of ADFS in season 1, it was possible to observe that all the hybrids presented reductions in the contents of ADFS with the application of fungicide. In this way, with the application of fungicide, it was observed a decrease of up to $8.8 \%$ ADFS for hybrid AS1572PRO. In season 2, only hybrid AS1572PRO showed no significant difference with the application of fungicide; however, for the other hybrids assessed, the application of fungicide reduced the contents of ADFS.

The results found indicate that the application of fungicide decreased the content of ADF for these hybrids, being this factor desired from the chemical point of view. According to Haerr et al. (2015), with the plant contamination by fungi there may occur an induced lignification of the cell wall, which tends to increase the contents of ADF of silage. Venancio et al. (2009) state that the chemical control with fungicides for foliar diseases in hybrids destined to silage production may cause changes in plant physiology, resulting in the decrease of the contents of lignin, a drop in the contents of ADF.

Thus, it was observed that the foliar fungicide application at two phenological stages (V8+R1) demonstrated beneficial effects in the chemical quality of maize silage, in both contents of NDF and ADF of maize forage and silage.

Similar results were reported by Haerr et al. (2016), who, when assessing the effect of fungicide application (pyraclostrobin + metconazole) on the 
chemical composition of maize hybrids for the production of silage in the USA, observed a linear drop in the contents of ADF with the foliar fungicide application. With two application (V5+R1), they observed a decrease of $1.13 \%$ in ADF content, and with three applications (V5+R1+R3), they still observed a decrease of $1.91 \%$ in ADF content.

In this same sense, Kalebich et al. (2017), when assessing the effect of foliar fungicide application (pyraclostrobin) on the chemical composition of maize silage in the same region as the previous study, observed a significant interaction between the application of fungicide and the content of ADF, showing that with two applications of fungicide (V5+R1), there was a reduction in the contents of $\mathrm{ADF}$ and morphological alterations in the plant, such as the decrease in the number of dry leaves and an increase in plant height, if compared to the treatment without application of fungicide.

These results demonstrate that the foliar fungicide application influences the chemical characteristics of forage and silage; which is desirable in the chemical perspective, because it reduces the contents of fiber carbohydrates, improving the nutritional quality of the food, and being a viable option for ruminant nutritionists and rural producers, who look for excellent zootechnical indices.

For DIGF, there was a statistical difference between the hybrids in relation to the application of fungicide (with and without), and between the groups of endosperms for both sowing seasons (Table 3).

Table 3

Mean results for forage digestibility (DIGF) and silage digestibility (DIGS) obtained for different maize hybrids, with and without foliar fungicide application, in two sowing seasons in the municipality of Guarapuava, State of Paraná, in the growing season of 2015/16

DIGF (\%)

\begin{tabular}{|c|c|c|c|c|c|c|}
\hline \multirow{4}{*}{ Hybrids } & \multicolumn{6}{|c|}{ DIGF (\%) } \\
\hline & \multicolumn{3}{|c|}{ Season 1} & \multicolumn{3}{|c|}{ Season 2} \\
\hline & \multicolumn{2}{|c|}{ Fungicide } & \multicolumn{4}{|c|}{ Fungicide } \\
\hline & Without & With & Mean & Without & With & Mean \\
\hline DKB240PRO & $47.18 \mathrm{bcB}$ & $54.53 \mathrm{abA}$ & 50.85 a & $42.87 \mathrm{bB}$ & $48.11 \mathrm{bA}$ & $45.49 \mathrm{~b}$ \\
\hline AS1572PRO & $51.99 \mathrm{aB}$ & $55.42 \mathrm{aA}$ & $53.71 \mathrm{a}$ & $48.15 \mathrm{aB}$ & $52.78 \mathrm{aA}$ & 50.47 a \\
\hline Medium VIT & $49.58 \mathrm{aB}$ & $54.97 \mathrm{aA}$ & & $45.51 \mathrm{aB}$ & 50.44 aA & \\
\hline 32R48YH & $43.14 \mathrm{cB}$ & $50.43 \mathrm{bA}$ & $46.78 \mathrm{~b}$ & $42.23 \mathrm{bB}$ & $49.55 \mathrm{abA}$ & $45.89 \mathrm{~b}$ \\
\hline AG8690PRO3 & $48.41 \mathrm{abB}$ & $56.65 \mathrm{aA}$ & $52.53 \mathrm{a}$ & $42.94 \mathrm{bB}$ & $47.86 \mathrm{bA}$ & $45.41 \mathrm{~b}$ \\
\hline \multirow[t]{2}{*}{ High VIT } & $45.77 \mathrm{bB}$ & $53.54 \mathrm{aA}$ & & $42.58 \mathrm{bB}$ & $48.71 \mathrm{aA}$ & CV $(\%) 4.86$ \\
\hline & \multicolumn{6}{|c|}{ DIGS (\%) } \\
\hline \multirow{3}{*}{ Hybrids } & \multicolumn{3}{|c|}{ Season 1} & \multicolumn{3}{|c|}{ Season 2} \\
\hline & \multicolumn{2}{|c|}{ Fungicide } & \multicolumn{4}{|c|}{ Fungicide } \\
\hline & Without & With & Mean & Without & With & Mean \\
\hline DKB240PRO & $55.31 \mathrm{aB}$ & $65.86 \mathrm{aA}$ & $60.58 \mathrm{a}$ & $49.78 \mathrm{abA}$ & $53.37 \mathrm{aA}$ & $51.58 \mathrm{~b}$ \\
\hline AS1572PRO & $55.41 \mathrm{aA}$ & $59.32 \mathrm{bA}$ & $57.36 \mathrm{ab}$ & $54.73 \mathrm{aA}$ & $58.02 \mathrm{aA}$ & $56.37 \mathrm{a}$ \\
\hline Medium VIT & $55.36 \mathrm{aB}$ & $62.59 \mathrm{aA}$ & & $52.25 \mathrm{aB}$ & $55.71 \mathrm{aA}$ & \\
\hline 32R48YH & $47.79 \mathrm{bB}$ & $56.33 \mathrm{bA}$ & 52.06 c & $40.41 \mathrm{cB}$ & $46.73 \mathrm{bA}$ & $43.56 \mathrm{c}$ \\
\hline AG8690PRO3 & $52.78 \mathrm{abB}$ & $60.08 \mathrm{abA}$ & $56.43 \mathrm{~b}$ & $47.54 \mathrm{bB}$ & $54.21 \mathrm{aA}$ & $50.87 \mathrm{~b}$ \\
\hline High VIT & 50.29 bB & $58.21 \mathrm{bA}$ & & $43.97 \mathrm{bB}$ & $50.47 \mathrm{bA}$ & CV(\%) 5.71 \\
\hline
\end{tabular}

Means followed by similar lowercase letters, in the same column, for the hybrids, and uppercase letters, in the same row, for the foliar fungicide application do not statistically differ from each other by Tukey's test at 5\% probability. 
Among the factors that may affect in situ digestibility of forage, and consequently, silage produced, includes the grain endosperm (Mendes, et al., 2015b). In this way, it is important to point out that regardless the sowing season, with and without the application of fungicide, there was a difference between the groups of endosperm, where the hybrids of the group with medium vitreous endosperm obtained the highest means of digestibility of forage and silage.

For season 1, it was possible to observe that with application of fungicide, there was an increase in the in situ forage digestibility, as well as for season 2. This was already expected, due to the reduction in the contents of NDF and ADF with the foliar application of fungicide previously observed.

A similar fact occurred with the in situ silage digestibility (DIGS); with the application of fungicide, it was possible to observe an increase in DIGS for the DKB240PRO, 32R48YH and AG8690PRO3 hybrids in season 1. For season 2, this increase was observed only for the $32 \mathrm{R} 48 \mathrm{YH}$ and AG8690PRO3 hybrids. This demonstrates that the foliar fungicide application positively influences the in situ digestibility of forage and silage.

Similar results were found by Haerr et al. (2016), who assessed the effect of foliar fungicide application on the in situ digestibility of maize silage, and pointed out an increase in the percentage of digestibility of the dry matter with the application of fungicide, if compared to the control treatment (without fungicide). They also noticed that the increase in the number of applications resulted in a linear rise of the in situ dry matter digestibility.

The results found in the present study corroborate Kalebich et al. (2017), who, when assessing the effect of the application of fungicide on the chemical composition of the silage using fractional hybrids, observed that with two applications of fungicide $(\mathrm{V} 5+\mathrm{R} 1)$, there was an increase in the digestible fraction of corn leaves, if compared to a single application (V5) and the control treatment (without fungicide).

In table 4 , the positive values of the contrast estimate indicate numerical superiority of WITHOUT (without fungicide) and SEASON 1 (October), while the negative values indicate more WITH (with fungicide) and SEASON 2 (December). The contrasts related to WITHOUT vs WITH (Table 4) were significant for all the characteristics assessed, again highlighting that the application of fungicide (WITH) influenced on the decrease of the contents of fiber and on the increase of digestibility of forage and silage.

For the contents of NDF and ADF of forage and silage, the contrast pointed out numerical superiority of the management of fungicide, which demonstrated that without the application of fungicide the contents of fibers were relatively higher in comparison to the application of fungicide. For the digestibility of forage and silage, it was possible to observe a higher index of the contrast WITH (with application of fungicide), showing that the chemical management with fungicide positively influenced the digestibility of the hybrids assessed.

The contrast of the interaction SEASON 1 vs SEASON 2 demonstrated a significant effect $(p<0.01)$ for all the chemical characteristics assessed, indicating superiority of SEASON 1. In this context, Mendes et al. (2015a) pointed out that several factors interfere with the final quality of silage and animal performance, being the sowing season one of the major factors to be considered and studied for silage production. 
Table 4

Estimate and probability of significance of the contrasts for neutral detergent fiber of forage (NDFF), acid detergent fiber of forage (ADFF), digestibility of forage (DIGF), neutral detergent fiber of silage (NDFS), acid detergent fiber of silage (ADFS) and digestibility of silage (DIGS) obtained for the different hybrids, without and with fungicide, in two sowing seasons in the municipality of Guarapuava, State of Paraná, in the growing season of $2015 / 2016$

\begin{tabular}{|c|c|c|c|c|}
\hline \multirow[b]{3}{*}{ Variable } & \multicolumn{2}{|c|}{ Fungicide } & \multicolumn{2}{|c|}{ Sowing } \\
\hline & \multicolumn{2}{|c|}{ WITHOUT vs WITH } & \multicolumn{2}{|c|}{ SEASON 1 vS SEASON 2} \\
\hline & Estimate & $P$ contrast & Estimate & $P$ contrast \\
\hline NDFF & 4.78 & $0.00 * *$ & -6.01 & $0.00 * *$ \\
\hline ADFF & 3.51 & $0.00 * *$ & -4.32 & $0.00 * *$ \\
\hline NDFS & 4.76 & $0.00 * *$ & -22.91 & $0.00 * *$ \\
\hline ADFS & 5.67 & $0.00 * *$ & -3.37 & $0.00 * *$ \\
\hline DIGF & -6.05 & $0.00 * *$ & 4.15 & $0.00 * *$ \\
\hline DIGS & -6.27 & $0.00 * *$ & 6.01 & $0.00 * *$ \\
\hline
\end{tabular}

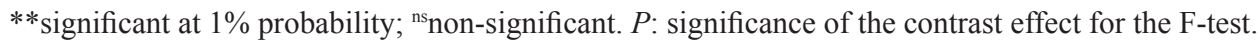

The application of fungicide in maize hybrids is used as a mechanism for plant protection, aiming especially at gains in the productivity of grains. In this sense, Kalebich et al. (2017) state that little is now known about the effects of the application of fungicide on the digestible fraction of the plant. Therefore, there is a need for more studies regarding the theme in order to understand the effect of the application of fungicide on the decrease of the contents of fiber carbohydrates in each part of the plant, and if there is a negative effect on the microbial metabolism in the rumen, mainly taking into consideration the fact that each part of the plant has a different proportion in maize silage.

\section{Conclusion}

The application of fungicide on forage maize hybrids decreased the contents of neutral detergent fiber (NDF) and acid detergent fiber (ADF) obtained soft dough stage of forage and in silage produced.

The sowing season in December negatively influenced the chemical parameters of forage maize hybrids, compared to sowing in October.
The hybrids with highly vitreous endosperm obtained the highest contents of NDF and ADF, soft dough stage of forage and in silage produced.

The application of fungicide (trifloxystrobin + prothioconazale) at the V8 and R1 stages positively influenced in situ digestibility soft dough stage of forage and in silage produced, regardless the sowing time.

\section{Acknowledgements}

This work was supported by CNPq (Conselho Nacional de Desenvolvimento Cientifico $e$ Tecnológico); and Capes (Coordenação de Aperfeiçoamento de Pessoal de Nivel Superior).

\section{References}

Arcari, M. A., Martins, C. M. M. R., Tomazi, T., \& Santos, M. V. (2016). Effect of the ensiling time of hydrated ground corn on silage composition and in situ starch degradability. Brazilian Journal of Veterinary Research and Animal Science, 53(1), 6071. doi: 10.11606/issn.1678-4456.v53i1p60-71 
Carvalho, G., Felipe, A., Martin, T. N., Santos, S., Müller, T. M., \& Piran, F. A., F . (2015). Perfil agronômico e bromatológico de silagem de milho no sudoeste do Paraná. Revista de La Facultad de Agronomía, 114(2), 149-159. Recuperado de https://dialnet. unirioja.es/servlet/articulo?codigo $=5718270$

Dombrink, M. A., \& Bietz, J. A. (1993). Zein composition in hard and soft endosperm of maize. Cereal Chemistry, 70(1), 105-108. Recovered from http:// naldc.nal.usda.gov/download/25448/PDF.

Ferreira, D. F. (2014). Sisvar: a guide for its bootstrap procedures in multiple comparisons. Ciência $e$ Agrotecnologia, 38(2), 109-112. doi: 10.1590/ S1413-70542014000200001

Giuberti, G., Gallo, A., Masoero, F., Ferraretto, L. F., Hoffman, P. C., \& Shaver, R. D. (2014). Factors affecting starch utilization in large animal food production system: a review. Starch-Stärke, 66(1-2), 72-90. doi: 10.1002/star.201300177

Gralak, E., Faria, M. V., Possato, O., Jr., Rossi, E. S., Silva, C. A., Rizzardi, D. A., \& Neumann, M. (2014). Capacidade combinatória de híbridos de milho para caracteres agronômicos e bromatológicos da silagem. Revista Brasileira de Milho e Sorgo, 13(2), 187-200. doi: 10.18512/1980-6477/rbms.v13n2p187-200

Haerr, K, J., Lopes, N. M., Pereira, M. N., Fellows, G. M., \& Cardoso, F. C. (2015). Corn silage from corn treated with foliar fungicide and performance of holstein cows. Journal of Dairy Science, 98(12), 8962-8972. doi: 10.3168/jds.2015-9887

Haerr, K. J., Pineda, A., Lopes, N. M., Weems, J. D., Bradley, C. A., Pereira, M. N.,... Cardoso, F. C. (2016). Effects of corn treated with foliar fungicide on in situ corn silage degradability in holstein cows. Animal Feed Science and Technology, 222(1), 149157. doi: 10.1016/j.anifeedsci.2016.10.010

Kalebich, C. C., Weatherly, M. E., Robinson, K. N., Fellows, G. M., Murphy, M. R., \& Cardoso, F. C. (2017). Foliar fungicide (pyraclostrobin) application effects on plant composition of a silage variety corn. Animal Feed Science and Technology, 225(1), 38-53. doi: 10.1016/j.anifeedsci.2016.12.016

Lima, M. L. M., Carvalho, E. R., Mattos, W. R. S., Nussio, L. G., Castro, F. G. F., \& Amaral, A. G. (2012). Comparação da fibra em detergente neutro de forragens: comportamento ingestivo e cinética ruminal. Revista Brasileira de Ciências Agrárias, 7(3), 535-542. doi: 10.5216/cab.v13i4.19468

Marafon, F., Neumann, M., Carletto, R., Wrobel, F. L., Mendes, E. D., Spada, C. A., \& Faria, M.
V. (2015). Características nutricionais e perdas no processo fermentativo de silagens de milho, colhidas em diferentes estádios reprodutivos com diferentes processamentos de grãos. Semina: Ciências Agrárias, 36(2), 917-932. doi: 10.5433/1679-0359.2015v36n2p917

Marcondes, M. M., Faria, M. V., Mendes, M. C., Gabriel, A., Neiverth, V., \& Zocche, J. C. (2016). Breeding potential of 44 maize lines in top crosses for agronomic and forage traits. Acta Scientiarum. Agronomy, 38(3), 307-315. doi: 10.4025/actasciagron.v38i3.28307

Mendes, M. C., Gabriel, A., Faria, M. V., Rossi, E. S., \& Possatto, O., Jr. (2015a). Época de semeadura de híbridos de milho forrageiro colhidos em diferentes estádios de maturação. Agroambiente, 9(2), 136-142. doi: 10.18227/1982-8470ragro.v9i2.2316

Mendes, M. C., Von Pinho, R. G., Pereira, M. N., Faria, E. M., Fo., \& Souza, A. X., F . (2008). Avaliação de híbridos de milho obtidos do cruzamento entre linhagens com diferentes níveis de degradabilidade da matéria seca. Bragantia, 67(2), 285-297. doi: 10.1590/S0006-87052008000200004

Mendes, M. H. S., Pereira, C. H., \& Souza, J. C. (2015b). Diallel analysis of maize hybrids for agronomic and bromatological forage traits. Acta Scientiarum. Agronomy, 37(2), 141-146. doi: 10.4025/ actasciagron. v37i2.19329

Momany, F. A., Sessa, D. J., Lawton, J. W., Selling, G. W., Hamaker, S. A., \& Willett, J. L. (2006). Structural characterization of alpha-zein. Journal of Agricultural and Food Chemistry, 54(2), 543-547. doi: $10.1021 / \mathrm{jf0} 88135 \mathrm{~h}$

Moraes, S. D., Jobim, C. C., Silva, M. S., \& Marquardt, F. I. (2013). Produção e composição química de híbridos de sorgo e de milho para silagem. Revista Brasileira Saúde e Produção Animal, 14(4), 624634. doi: 10.1590/S1519-99402013000400002

Neumann, M., Figueira, D. N., Faria, M. V., Mendes, M. C., \& Carneiro, M. K. (2015). Comportamento produtivo de híbridos de milho (Zea mays) para produção de silagem. Brazilian Journal of Applied Technology for Agricultural Science, 8(3), 63-71. doi: 10.5935/PAeT.V8.N3.07

Neumann, M., Ost, P. R., Pellegrini, L. G., \& Defaveri, F. J. (2008). Comportamento de híbridos de milho (Zea mays) e sorgo (Sorghum bicolor) para silagem na região centro-sul do Paraná. Ambiência Guarapuava, 4(2), 237-250. Recuperado de https:// revistas.unicentro.br/index.php/ambiencia/article/ viewFile/165/201 
Peel, M. C., Finlayson, B. L., \& McMahon, T. A. (2007). Updated world map of the Köppen-Geiger climate classification. Hydrology Earth System Science, 1(11), 1633-1644. doi: 10.5194/hess-11-1633-2007

Pereira, J. L. D. A. R., Von Pinho, R. G., Souza, A. X., Fo., Pereira, M. N., Santos, Á. D. O., \& Borges, I. D. (2012). Quantitative characterization of corn plant components according to planting time and grain maturity stage. Revista Brasileira de Zootecnia, 41(5), 1110-1117. doi: 10.1590/S151635982012000500005

Ribas, M. N., Gonçalves, L. C., Ibrahim, G. H. F., Rodriguez, N. M., Borges, A. L. C. C., \& Borges, I. (2007). Consumo e digestibilidade aparente de silagens de milho com diferentes graus de vitreosidade no grão. Revista Brasileira de Milho e Sorgo, 6(1), 104-115. doi: 10.18512/1980-6477/ rbms.v6n1p104-115

Rossi, E. S., Faria, M. V., Mendes, M. C., Neumann, M., Gabriel, A., \& Del Conte, M. V. (2016a). Bromatological characteristics and ruminal digestibility of grain corn hybrids with different vitreousness in silage maturity. Acta Scientiarum, Agronomy, 38(3), 337-344. doi: 10.4025/ actasciagron.v38i3.28703
Rossi, E. S., Faria, M. V., Mendes, M. C., Possatto, O., Neumann, M., \& Jobim, C. C. (2016b). Características bromatológicas do grão e forragem de híbridos de milho com diferentes texturas de grãos. Agrária, Revista Brasileira de Ciências Agrárias, 11(2), 132141. doi: 10.5039/agraria.v11i2a5363

Van Soest, P. J., Robertson, J. B., \& Lewis, B. A. (1991). Methods for dietary fiber, neutral detergent fiber, and no starch polysaccharides in relation to animal nutrition. Journal of Dairy Science, 74(10), 35833597. doi: 10.3168/jds.S0022-0302(91)78551-2

Venancio, W. S., Rodrigues, M. A. T., Begliomini, E., \& Souza, N. L. (2009). Physiological effects of strobilurin fungicides on plants. Ciências Exatas $e$ da Terra, Agrárias e Engenharia, 9(1), 59-68. doi: 10. 5212/publicatio.v9i03.814

Vieira, V. C., Martin, T. N., Menezes, L. F. G., Ortiz, S., Bertoncelli, P., \& Storck, L. (2013). Caracterização bromatológica de silagens de milho de genótipos super precoce. Ciência Rural, 43(11), 1925-1931 doi: 10.1590/S0103-84782013001100001 
